\title{
Development of a compact heat storage system based on salt hydrates
}

\author{
V.M. van Essen \\ L.P.J. Bleijendaal \\ B.W.J. Kikkert \\ H.A. Zondag \\ M. Bakker \\ P.W. Bach
}

Presented at the International Conference on Solar Heating, Cooling and Buildings 28 September - 1 October 2010, Graz, Austria 


\title{
DEVELOPMENT OF A COMPACT HEAT STORAGE SYSTEM BASED ON SALT HYDRATES
}

\author{
V.M. van Essen $^{1}$, L.P.J. Bleijendaal ${ }^{1}$, B.W.J. Kikkert ${ }^{1}$, H.A. Zondag $^{1,2}$, M. Bakker ${ }^{1}$, and P.W. \\ Bach $^{1}$ \\ ${ }^{1}$ ECN, Energy Research Centre of the Netherlands, P.O. Box 1, 1755 ZG Petten, the Netherlands, \\ Telephone: +31 22456 4806, fax: +31 22456 8966, email: v.vanessen@ecn.nl. \\ ${ }^{2}$ Department of Mechanical Engineering, Eindhoven University of Technology (TU/e), 5600 MB Eindhoven, \\ The Netherlands
}

\begin{abstract}
Thermochemical reactions are one of the most promising means for compact, low loss and long term storage of solar heat in the built environment. The heat can be stored by making use of a reversible chemical reaction. In theory, an energy density 5-10 times higher than water can be reached. Additionally, no storage losses are associated with thermochemical heat storage. Thermochemical materials have been identified that are cheap, non-toxic, have sufficient energy density and have reaction temperatures that can be reached by a vacuum tube collector. These requirements are fulfilled by a number of salt hydrates. A detailed study at ECN identified $\mathrm{MgCl}_{2} \cdot 6 \mathrm{H}_{2} \mathrm{O}$ as the most promising salt hydrate for compact seasonal heat storage. The material was found to be capable of storing and releasing heat under practical conditions. In the present paper, the results on $\mathrm{MgCl}_{2} \cdot 6 \mathrm{H}_{2} \mathrm{O}$ characterization and the first results using a fixed bed reactor will be presented.
\end{abstract}

\section{Introduction}

Traditional heat storage techniques have a number of disadvantages for seasonal heat storage, such as substantial heat losses and relatively low energy densities. It means that a seasonal heat storage system requires a large storage tank $\left(>40 \mathrm{~m}^{3}\right)$ for seasonal heat storage. However, these tanks are too large to be placed inside a building. As an alternative, it is possible to store heat by making use of a reversible chemical reaction: $\mathrm{TCM}+$ heat $\leftrightarrow \mathrm{A}+\mathrm{B}$. In the summer, the thermochemical material (TCM) dissociates under influence of solar heat into components $\mathrm{A}$ and $\mathrm{B}$, which are stored separately. In the winter, the two components (A and B) react to form the original TCM while releasing the stored solar heat. No reactions occur as long as the two components are stored separately, which means that thermochemical storage can be used for loss-free storage and transportation of heat. Additionally, a theoretical energy density of 5-10 times higher than water can be reached, which offers a more compact way of storing heat than using traditional heat storage techniques.

Not all TCMs are suitable for seasonal solar heat storage in the built environment. Besides common conditions such as low costs, safety and reliable operation, TCMs have to be non-poisonous, must have sufficient energy density and have reaction temperatures that can be reached by a medium temperature solar collector. These requirements are fulfilled by a large number of salt hydrates. A theoretical study performed at $\mathrm{ECN}$ identified four promising salt hydrates: $\mathrm{MgSO}_{4} \cdot 7 \mathrm{H}_{2} \mathrm{O}, \mathrm{Al}_{2}\left(\mathrm{SO}_{4}\right)_{3} \cdot 18 \mathrm{H}_{2} \mathrm{O}$, 
$\mathrm{CaCl}_{2} \cdot 2 \mathrm{H}_{2} \mathrm{O}$ and $\mathrm{MgCl}_{2} \cdot 6 \mathrm{H}_{2} \mathrm{O}$ [1]. These salt hydrates were further investigated under practical conditions on their potential for compact seasonal heat storage in the built environment. Based on these experiments, the most promising salt hydrate is selected for further tests in a newly constructed atmospheric pressure fixed bed reactor. In the present paper, the results of the material selection experiments and first experiments using the newly constructed atmospheric pressure fixed bed reactor are presented and discussed.

\section{General description of the TCM heat storage system}

A salt hydrate has to be able to store and release heat under practical conditions. These conditions are determined by the TCM heat storage system, where the heat is stored or release by means of the reaction: salt. $\mathrm{nH}_{2} \mathrm{O}(\mathrm{s})+$ heat $\leftrightarrow$ salt $(\mathrm{s})+\mathrm{nH}_{2} \mathrm{O}(\mathrm{g})$. During the summer, a vacuum tube collector array is used to dehydrate the salt hydrate $\left(\mathrm{salt}_{\mathrm{nH}} \mathrm{O}\right)$ thereby storing solar heat. In this paper, it is assumed that these collectors deliver heat at a maximum temperature of $150^{\circ} \mathrm{C}$. The dehydrated salt and the water vapor (in condensed form) are stored in separate vessels. In the winter, the water vapor and the salt are brought together in order to release the stored solar heat. The water is evaporated by means of heat from a borehole heat exchanger. It is assumed that the borehole is at a constant temperature of $10^{\circ} \mathrm{C}$ during the year. It means that a (saturation) water vapor pressure at $10^{\circ} \mathrm{C}$, which is equal to 1.3 $\mathrm{kPa}$, is available for hydration in the winter. The released solar heat can be used, for example, for floor heating, which normally operates at maximum inflow temperatures of $40^{\circ} \mathrm{C}$. It means that the salt hydrate should be able to hydrate and release heat at these temperatures and a water vapor pressure of $1.3 \mathrm{kPa}$.

\section{Detailed material selection for compact seasonal heat storage in the built environment}

A detailed theoretical study was performed to investigate which material is suitable for the TCM heat storage system in the built environment $[1,2,4]$. This study included all known absorbents (hydrates, ammoniacates, ethanolates, etc.) and adsorbents (zeolites, silica gel, etc.). The materials were evaluated based on energy density, costs, toxicity and temperature lifts, taking into account the various reaction steps during heat storage and release. Table 1 shows the four most promising salt-water reversible reactions with corresponding energy density as identified in the theoretical study [1,2].

Table 1. Selected salt-water vapor reversible reactions with corresponding energy densities [1,2]. For comparison, the energy density for heating up water is also presented.

\begin{tabular}{|c|c|c|}
\hline Reaction & $\begin{array}{c}\text { Solid density } \\
\text { salt hydrate } \\
\left(\mathbf{k g} / \mathbf{m}^{3}\right)\end{array}$ & $\begin{array}{c}\text { Theoretical energy } \\
\text { density }\left(\mathbf{G J} / \mathbf{m}^{3}\right)\end{array}$ \\
\hline $\mathrm{MgSO}_{4} \cdot 7 \mathrm{H}_{2} \mathrm{O}(\mathrm{s}) \leftrightarrow \mathrm{MgSO}_{4}(\mathrm{~s})+7 \mathrm{H}_{2} \mathrm{O}(\mathrm{g})$ & 1680 & 2.80 \\
\hline $\mathrm{Al}_{2}\left(\mathrm{SO}_{4}\right)_{3} \cdot 18 \mathrm{H}_{2} \mathrm{O}(\mathrm{s}) \leftrightarrow \mathrm{Al}_{2}\left(\mathrm{SO}_{4}\right)_{3}(\mathrm{~s})+18 \mathrm{H}_{2} \mathrm{O}(\mathrm{g})$ & 1690 & 2.75 \\
\hline $\mathrm{MgCl}_{2} \cdot 6 \mathrm{H}_{2} \mathrm{O}(\mathrm{s}) \leftrightarrow \mathrm{MgCl}_{2} \cdot \mathrm{H}_{2} \mathrm{O}(\mathrm{s})+5 \mathrm{H}_{2} \mathrm{O}(\mathrm{g})$ & 1560 & 2.48 \\
\hline $\mathrm{CaCl}_{2} \cdot 2 \mathrm{H}_{2} \mathrm{O}(\mathrm{s}) \leftrightarrow \mathrm{CaCl}_{2}(\mathrm{~s})+2 \mathrm{H}_{2} \mathrm{O}(\mathrm{g})$ & 1710 & 1.44 \\
\hline Heating up water $\left(\Delta \mathrm{T}=60^{\circ}\right)$ & - & 0.25 \\
\hline
\end{tabular}




\subsection{Dehydration of four promising salt hydrates under practical conditions}

All four salt hydrates were dehydrated in an oven to investigate the dehydration behavior of the four selected salt hydrates under practical conditions. The salt hydrates were heated from room temperature to $150^{\circ} \mathrm{C}$, which corresponds to the temperature that can be reached by a vacuum tube collector (see above). At $150^{\circ} \mathrm{C}$, the samples were held isothermally for at least 2 hours. In the previous study on $\mathrm{MgSO}_{4} \cdot 7 \mathrm{H}_{2} \mathrm{O}$ it was found that melting occurred when heating the sample with a heating rate > $1{ }^{\circ} \mathrm{C} / \mathrm{min}[5,6]$. For this reason, it was decided to use a constant heating rate of $1{ }^{\circ} \mathrm{C} / \mathrm{min}$. Based on the measured mass loss after dehydration in the oven, the following reactions were found:

Table 2. Dehydration reactions determined from mass loss measurements and associated theoretical energy densities.

\begin{tabular}{|l|c|}
\hline \multicolumn{1}{|c|}{ Dehydration reaction } & $\begin{array}{c}\text { Theoretical } \\
\text { energy density } \\
\left(\mathrm{GJ} / \mathrm{m}^{3}\right)\end{array}$ \\
\hline $\mathrm{MgSO}_{4} \cdot 7 \mathrm{H}_{2} \mathrm{O}(\mathrm{s}) \rightarrow \mathrm{MgSO}_{4} \cdot \mathrm{H}_{2} \mathrm{O}(\mathrm{s})+6 \mathrm{H}_{2} \mathrm{O}(\mathrm{g})$ & 2.47 \\
\hline $\mathrm{Al}_{2}\left(\mathrm{SO}_{4}\right)_{3} \cdot 18 \mathrm{H}_{2} \mathrm{O}(\mathrm{s}) \rightarrow \mathrm{Al}_{2}\left(\mathrm{SO}_{4}\right)_{3} \cdot 5 \mathrm{H}_{2} \mathrm{O}(\mathrm{s})+13 \mathrm{H}_{2} \mathrm{O}(\mathrm{g})$ & $2.16^{*}$ \\
\hline $\mathrm{MgCl}_{2} \cdot 6 \mathrm{H}_{2} \mathrm{O}(\mathrm{s}) \rightarrow \mathrm{MgCl}_{2} \cdot 2 \mathrm{H}_{2} \mathrm{O}(\mathrm{s})+4 \mathrm{H}_{2} \mathrm{O}(\mathrm{g})^{* *}$ & 2.12 \\
\hline $\mathrm{CaCl}_{2} \cdot 2 \mathrm{H}_{2} \mathrm{O}(\mathrm{s}) \rightarrow \mathrm{CaCl}_{2}(\mathrm{~s})+2 \mathrm{H}_{2} \mathrm{O}(\mathrm{g})$ & 1.44 \\
\hline
\end{tabular}

*Theoretical enthalpy of formation for $\mathrm{Al}_{2}\left(\mathrm{SO}_{4}\right)_{3} .5 \mathrm{H}_{2} \mathrm{O}$ of $-5000 \mathrm{~kJ} / \mathrm{mol}$ was found by fitting enthalpies of formation for hydrates of aluminum sulfate from Ref [7] as function of the amount of hydrated water molecules.

** During the dehydration, a small amount of $\mathrm{HCl}$ was formed. See text for more details.

In all cases, the salt hydrates can be dehydrated at $150^{\circ} \mathrm{C}$, which means that all four promising salt hydrates can be used for solar heat storage using a vacuum tube collector. It should be noted that, with the exception of $\mathrm{CaCl}_{2} \cdot 2 \mathrm{H}_{2} \mathrm{O}$, an anhydrate is not formed at $150^{\circ} \mathrm{C}$ as might be anticipated based on the reactions shown in Table 1. However, this result is not unexpected since most anhydrates are formed at relatively high temperature, which cannot be reached by a vacuum tube collector. For example, $\mathrm{MgSO}_{4}$ was formed near $300^{\circ} \mathrm{C}$ [5]. Additionally, the dehydration of salt hydrates often proceeds in discrete steps instead of a single step [1,4-6]. Not all dehydration steps are associated with a high energy density $[1,5]$. This is confirmed by the results shown in Table 2, where high energy densities can be reached although the material is not completely dried.

During the dehydration of $\mathrm{MgCl}_{2} \cdot 6 \mathrm{H}_{2} \mathrm{O}$ at temperatures above $138^{\circ} \mathrm{C}$, hydrochloric acid was formed and detected. The hydrochloric acid $(\mathrm{HCl})$ is probably formed via hydrolysis of the magnesium chloride dihydrate [8]:

$$
\mathrm{MgCl}_{2} \cdot 2 \mathrm{H}_{2} \mathrm{O}(\mathrm{s}) \rightarrow \mathrm{MgOHCl}(\mathrm{s})+\mathrm{HCl}(\mathrm{g})+\mathrm{H}_{2} \mathrm{O}(\mathrm{g})
$$

The formation of $\mathrm{HCl}$ is undesired in the built environment, but also the formation of $\mathrm{MgOHCl}$ is undesired since it is unable to take up water and release heat after dehydration. Further research revealed that between $130^{\circ} \mathrm{C}$ and $138^{\circ} \mathrm{C}$, the dehydration reaction in Table 2 proceeds without the formation of $\mathrm{HCl}$. For this reason it was decided to dehydrate $\mathrm{MgCl}_{2} \cdot 6 \mathrm{H}_{2} \mathrm{O}$ at $130^{\circ} \mathrm{C}$. 


\subsection{Experimental setup for studying hydration behavior of the four promising salt hydrates}

Within the WAELS project, a Dutch national long-term research project, $\mathrm{MgSO}_{4} \cdot 7 \mathrm{H}_{2} \mathrm{O}$ was investigated as promising material for long term heat storage. It was found that this material can be dehydrated at temperatures below $150^{\circ} \mathrm{C}$. Additionally, the material was able to store $2.2 \mathrm{GJ} / \mathrm{m}^{3}$, almost 9 times more energy than can be stored in water as sensible heat. However, no heat was released under practical conditions at atmospheric pressure [5]. It was therefore tried to hydrate the material under low-pressure conditions, which should enhance diffusion of the water vapor towards the material and thereby improve the heat release. The results of the magnesium sulfate hydration are compared with hydration results for the other three salts using the same evacuated fixed bed setup.

An evacuated fixed bed reactor was constructed to investigate the potential of the four promising salt hydrates at low-pressure. The experimental setup is shown in Fig.1.
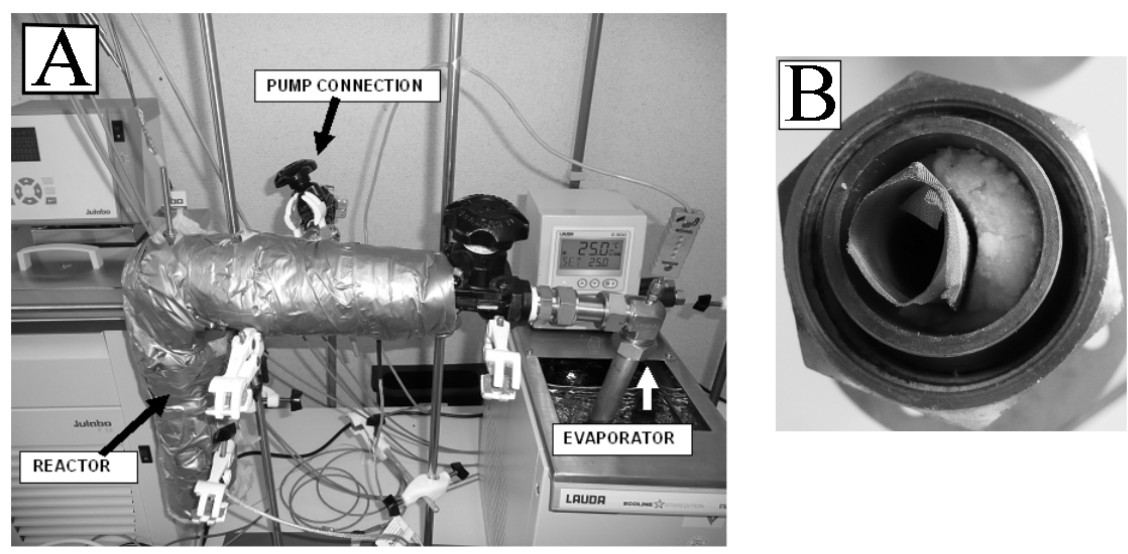

Fig. 1. A. Picture of experimental setup for analyzing the four salt hydrates, B. Top view of fixed bed reactor filled with the salt hydrate

The evacuated fixed bed reactor shown in Fig. 1A is capable of storing 40 grams of the dehydrated salt. In the centre of the reactor a cylindrical metal mesh is placed with aperture size of 40 micron and diameter of $1 \mathrm{~cm}$ (see also Fig 1.B). The metal mesh acts as a vapor channel to facilitate the water transport to the salt during the hydration. A heating cable was wrapped around the fixed bed reactor to keep the reactor at a constant temperature.

The fixed bed reactor is connected to an evaporator and a vacuum pump system. The evaporator is immersed in a thermostat bath to control the temperature of the water inside the evaporator. A vacuum pump system consisting of a pressure sensor and two diaphragm vacuum pumps in series is used to evacuate the system to a minimum pressure of 2.8 mbar. During the measurements, the temperature inside the fixed bed reactor and the evaporator are monitored by K-type thermocouples. The data from the thermocouples is digitized using a data acquisition unit and subsequently stored on a PC.

\subsection{Hydration of four promising salt hydrates under practical conditions}

All four salt hydrates were dehydrated inside an oven prior to the experiments. The oven was programmed to heat up the samples from room temperature to $150^{\circ} \mathrm{C}$ with $1{ }^{\circ} \mathrm{C} / \mathrm{min}$ as described above. The $\mathrm{MgCl}_{2} \cdot 6 \mathrm{H}_{2} \mathrm{O}$ sample was also dehydrated at $150^{\circ} \mathrm{C}$ because the $\mathrm{HCl}$ formation during 
dehydration was unknown during these hydration experiments. The dehydrated salt from the oven is placed inside the fixed bed reactor. In the first experiments, the evaporator is at $10^{\circ} \mathrm{C}$, which corresponds to the temperature of the bore hole heat exchanger. As mentioned earlier, the goal is to use the stored solar for space heating which normally operates at $40^{\circ} \mathrm{C}$. It means that the salt should be able to release heat above $40^{\circ} \mathrm{C}$ when taking into account the heat losses between the storage system and the space heating system. Therefore an initial reactor temperature of $50^{\circ} \mathrm{C}$ was used during some of the hydration experiments.

In the previous study on $\mathrm{MgSO}_{4} \cdot 7 \mathrm{H}_{2} \mathrm{O}$ it was found that the dehydrated material did not release heat when exposed to $1.3 \mathrm{kPa}$ water vapor pressure, which is the saturation water vapor pressure at $10^{\circ} \mathrm{C}$. However, $\mathrm{MgSO}_{4} \cdot 7 \mathrm{H}_{2} \mathrm{O}$ did release heat when the evaporator was set at $25^{\circ} \mathrm{C}$ [5]. Therefore it was decided to also study the hydration behavior when both reactor and evaporator temperature are set at $25^{\circ} \mathrm{C}$. The results of the hydration experiments for all four salt hydrates in evacuated fixed setup are shown in Fig. 2.

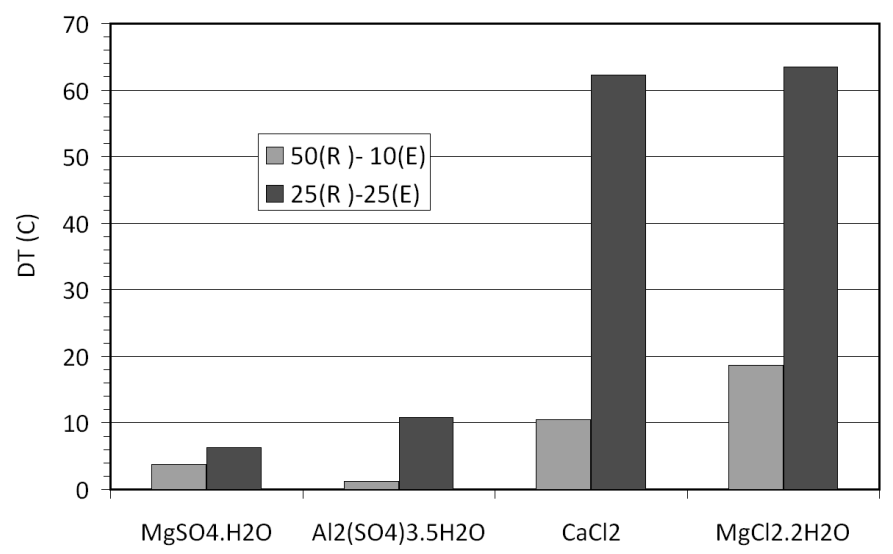

Fig. 2. Measured maximum temperature increase (DT) for the four salt hydrates tested in the fixed bed reactor. R denotes reactor temperature, $\mathrm{E}$ denotes evaporator temperature. The setup was evacuated to 2.8 mbar prior to the experiments.

The hydration results show that all salts are able to release heat during hydration. However, a clear difference is observed between the sulfate and the chloride salts: significantly higher temperature lifts can be observed using the chlorides under similar conditions. This effect was also observed by other authors, where water uptake by sulfates (except lithium sulfate) was found to be kinetically hindered $[9,10]$. On the other hand, the chloride salt hydrates are hygroscopic and found to agglomerate during hydration. Nevertheless, based on the observed temperature lift, it was decided to select $\mathrm{MgCl}_{2} \cdot 6 \mathrm{H}_{2} \mathrm{O}$ for further experiments.

\section{Atmospheric pressure fixed bed reactor}

At ECN, a first analysis of the economical feasibility of thermochemical heat storage systems was made and compared with costs of competing options such as fossil based options and fully renewable alternatives [3]. Four thermochemical heat storage systems were evaluated: fixed bed reactor and separate reactor with a transport screw, both operating at either atmospheric or low-pressure 
conditions. The system costs were calculated assuming a 30 year lifetime and a passive house with a 6 GJ heating demand and a 9 GJ hot water demand. The study identified the atmospheric pressure fixed bed reactor as the most cost-effective system. For this reason, it was decided to construct and evaluate the technical potential of an atmospheric pressure fixed bed reactor under practical conditions.

\subsection{Description of the experimental setup}

The previous experiments were conducted using a small evacuated fixed bed reactor which is capable of storing 40 grams of dehydrated salt. In order to investigate the heat storage (and release) capabilities of $\mathrm{MgCl}_{2} \cdot 6 \mathrm{H}_{2} \mathrm{O}$ under atmospheric pressure conditions using larger samples, it was decided to construct a new fixed bed reactor which is shown in Fig. 3.

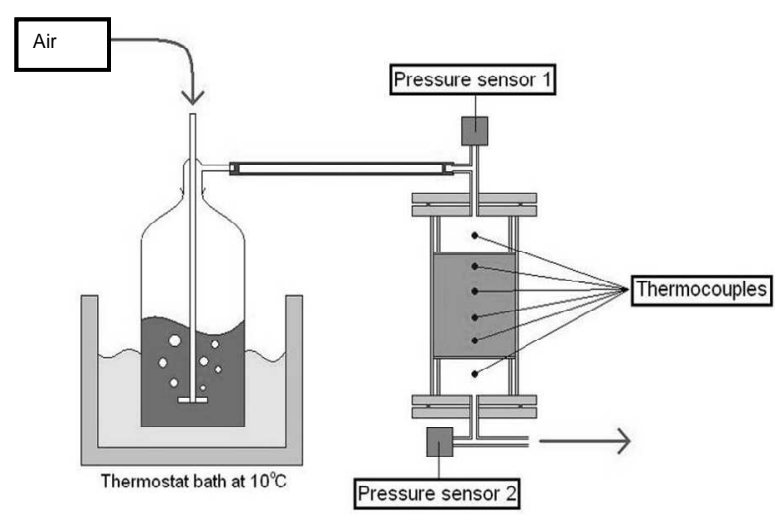

Fig. 3 Schematic representation of the atmospheric pressure fixed bed reactor (including the evaporator). The arrows denote the flow direction.

Prior to the experiments, the cylindrical fixed bed reactor is filled with $~ 300-350$ gram salt, which was

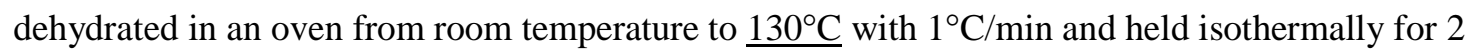
hours. The bed material is held between two filter plates. The temperature in the bed is measured with four K-type thermocouples at a mutual distance of $3 \mathrm{~cm}$. The thermocouples are located above each other in the middle of the bed. Also, the temperatures of the air flow entering and leaving the bed are both monitored by K-type thermocouples. Two pressure sensors are located on the top and bottom of the reactor to measure the pressure difference over the bed. The reactor is insulated with $2 \mathrm{~cm}$ glass wool.

At the start of the experiment, dry air flows through a bubbling flask filled with water (left side in Fig. 3 ). A thermostat bath is used to keep the temperature of the water at $10^{\circ} \mathrm{C}$. The moist air flow from the bubble flask is directed to the top of the fixed bed reactor instead of going to the bottom of the reactor to prevent fluidization at high flow rates. On its way to the reactor, the moist air flow is slowly heated up to ambient temperature, since it was practically too difficult to keep the transporting tube at $10^{\circ} \mathrm{C}$. Nevertheless, experiments reveal that the water vapor pressure remains constant at $1.3 \mathrm{kPa}$.

\subsection{First results using magnesium chloride in the atmospheric pressure fixed bed reactor}

A sample of 344 gram $\mathrm{MgCl}_{2} \cdot 6 \mathrm{H}_{2} \mathrm{O}$ was dehydrated in an oven by heating the material from $25^{\circ} \mathrm{C}$ to $130^{\circ} \mathrm{C}$ with $1{ }^{\circ} \mathrm{C} / \mathrm{min}$ and held isothermally for 2 hours. Based on the mass change, the final product of the dehydration was found to be $\mathrm{MgCl}_{2} \cdot 2 \mathrm{H}_{2} \mathrm{O}$. The material was placed inside the fixed bed reactor. 
An air flow of $20 \mathrm{slpm}$ was used to hydrate the material. During the hydration, it was discovered that the thermocouples in the bed were displaced as shown in Fig. 4A.

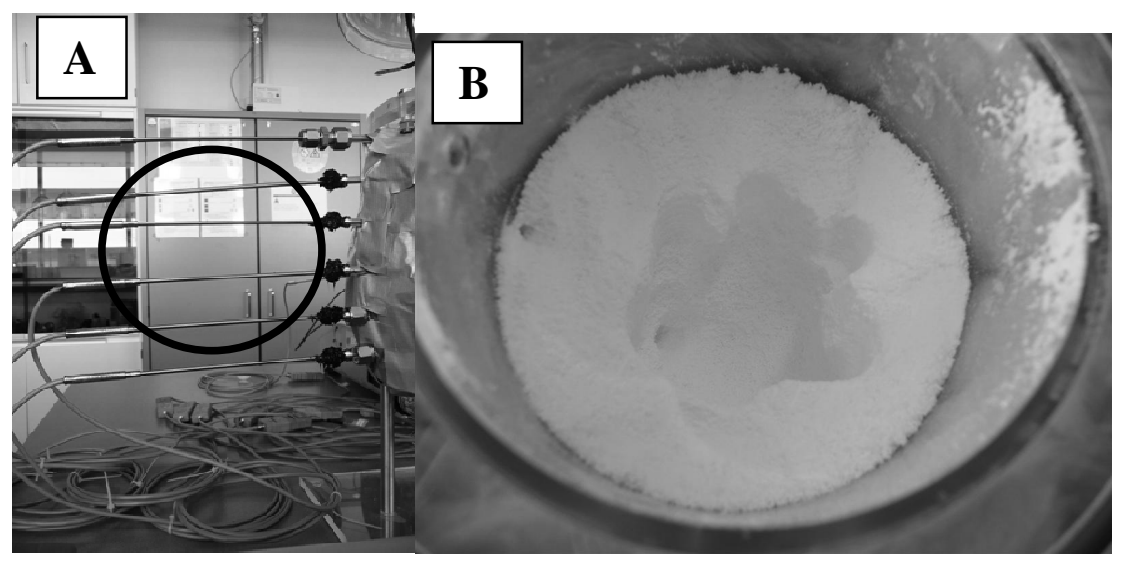

Fig. 4. (A). Displacement of the thermocouples as seen from the outside of the reactor. The first and last thermocouples monitor the air temperature, while the other thermocouples (indicated with a black circle) are located inside the bed. (B). Top of the reactor bed after hydration. The holes are made by a drill in order to estimate the thickness of the hard impermeable layer.

The initial position of all thermocouples was horizontal and parallel to each other. It can be clearly seen that the second and third thermocouple, which are located in the bed, are bend away from the horizontal. After the hydration it was found during the salt had expanded and pushed against the cover filter plate and the thermocouples.

During the hydration measurement, an increase in pressure drop over the bed was observed, which was caused by a hard impermeable layer with a thickness of $\sim 2 \mathrm{~cm}$ was formed at the top of the bed (see also Fig. 4B). The formation of this hard impermeable layer is undesired since it destroys the open structure of the bed and prevents efficient hydration.

\section{Conclusions \& outlook}

An extensive literature inventory identified four promising salt hydrates $\left(\mathrm{MgCl}_{2} \cdot 6 \mathrm{H}_{2} \mathrm{O}, \mathrm{CaCl}_{2} \cdot 2 \mathrm{H}_{2} \mathrm{O}\right.$, $\mathrm{MgSO}_{4} \cdot 7 \mathrm{H}_{2} \mathrm{O}$ and $\left.\mathrm{Al}_{2}\left(\mathrm{SO}_{4}\right)_{3} .18 \mathrm{H}_{2} \mathrm{O}\right)$ for compact seasonal heat storage in the built environment.

Experiments show that all four salt hydrates can be dehydrated at $150^{\circ} \mathrm{C}$ which can be reached by a medium temperature solar collector. It was also found that the $\mathrm{HCl}$ gas that was formed during the dehydration of $\mathrm{MgCl}_{2} \cdot 6 \mathrm{H}_{2} \mathrm{O}$ can be avoided by dehydrating at $130^{\circ} \mathrm{C}$. Hydration experiments in an evacuated fixed bed reactor reveal that the chlorides show a larger temperature lift than the sulfates. However, the chlorides were found to agglomerate during hydration. Based on the observed temperature, $\mathrm{MgCl}_{2} \cdot 6 \mathrm{H}_{2} \mathrm{O}$ was chosen for further experiments using an newly constructed atmospheric pressure fixed bed reactor. The experimental results show that the material expands and forms a hard impermeable layer during hydration.

A possible solution to the problems observed during the hydration of $\mathrm{MgCl}_{2} \cdot 2 \mathrm{H}_{2} \mathrm{O}$ is to use a carrier material that is flexible enough to absorb the expansion of the salt without (significantly) reducing the open structure of the bed. Additionally, the carrier material should also be able to prevent 
overhydration. Currently an literature overview is made of possible candidate carrier materials and first experiments are planned.

\section{Acknowledgement}

The work on thermochemical heat storage is part of the long-term work at ECN on compact storage technologies

\section{References}

[1] Zondag, H.A., 2007, "Literatuurinventarisatie van Thermochemische materialen”, internal ECN memo

[2] Visscher, K. Veldhuis, J.B.J., Oonk, H.A.J., van Ekeren, P.J. and Blok, J.G.,. (2004) ECN Report ECN-C04-074: Compacte chemische seizoenopslag van zonnewarmte; Eindrapportage, ECN, Petten

[3] Zondag, H.A., Essen, V.M. van, Bakker, M, Bach, P., Laevemann, E., and Hauer, A. “ Economical feasibility of sorption heat storage", submitted for IRES V 2010 conference, Berlin, Germany

[4] Essen, V.M. van, Cot Gores, J. and Zondag, H.A., "Literature inventory on thermo chemical materials", internal ECN memo

[5] Essen, V.M. van, Zondag, H.A., Cot Gores, J., Bleijendaal, L.P.J., Bakker, M., Schuitema, R., Helden, W.G.J. van, He, Z., and Rindt, C.C.M., J.Sol Energy Engineering, 131(4), 041014, 2009

[6] Zondag, H., Essen, V.M. van, He, Z., Schuitema, R. and Helden, W. van, 2007, "Characterization of MgSO4 for thermochemical storage", in Second International Renewable Energy Storage Conference (IRES II), Bonn, Germany

[7] Wagman, D. D., Evans, W. H., Parker, V. B., Schumm, R. H. and Halow, I., J. Phys. Chem. Ref. Data 11 (1982)

[8] Kipouros, G.J., and Sadoway, D.R., J.Light Metals 1 (2001), 111-117

[9] Jonsson, S., 2000, A Chemical Heat Pump Using A Solid Substance, Int. Patent. Nr. WO 00/31206

[10] Steiger, M., and Linnow, K., Crystal Growth \& Design, 8 (2008), 336-343 